\section{Elisabeth Snyman}

Elisabeth Snyman is a retired Professor in French who works as a researcher at the School of Languages of the North-West University, Potchefstroom.

Email: Elisabeth.Snyman@nwu.ac.za

\author{
Véronique Tadjo: Is there hope \\ beyond the divisions in \\ contemporary Africa?
}

\title{
Is there hope beyond the divisions in contemporary Africa?
}

This article discusses the Ivorian author Véronique Tadjo's representation of separation and division in a post-colonial African context through a close reading of three of her texts, namely The Blind Kingdom (1990), Queen Pokou. Concerto for a sacrifice (2004) and Far from my Father (2010). In Tadjo's novelistic universe, such divisions often require the intervention of a female protagonist, whose own existence is deeply influenced by tensions and frictions between two opposing camps. I shall argue that the agency of these protagonists is never futile and may even point to a way to go beyond the original divisions. Tadjo's representation of division also transgresses generic boundaries to address socio-political problems in unique ways. I shall demonstrate how the author draws on various genres such as poetry, the African folktale, the novel, as well as autofiction in order to engage the reader in a profound reflexion on the current state and future of the African continent. Keywords: Franchophone women's writing, Véronique Tadjo, social divisions within a nation.

Right from the start of her career as a writer, the Ivorian author Véronique Tadjo questions contemporary Africa in an oeuvre focussed on socio-political divisions on the continent. The present article proposes a reading of three texts, namely The Blind Kingdom (1990), Queen Pokou. Concerto for a sacrifice (2004) and Far from my father (2010), in order to examine the author's representation of, and reflexion on, separation and division, be it within a nation, amongst groups, or in the heart of a family. ${ }^{1}$ The reasons for this choice are firstly, that these texts have received less attention from scholars than for instance The Shadow of Imana (2000), and secondly, because reading them together highlights the interconnectedness of Tadjo's oeuvre.

Although it is clear that the socio-political problems of her country lie at the heart of her own involvement in the African continent and her search for hope and solutions through her writing, the scope of the author's endeavour is not limited to the problems of one country. The vagueness of spatio-temporal settings that characterises works like The Blind Kingdom, Champs de bataille et d'amour (1999; not yet translated into English) and Queen Pokou, gives a universal quality to the author's depiction of Ivorian socio-political divisions. On the other hand, texts situated clearly within a specific space and time, like The Shadow of Imana, and Far from my father, also carry messages that reach beyond their historical anchorage. 
The proposed analysis will refer to interviews with, and articles written by Tadjo as well as lectures she delivered, to support some of its findings, however, without losing sight of the fact that what an author creates in a literary text cannot simply be considered on the same level as her own interpretation of her work in other contexts. The text as a work of art, should speak for itself. Does not Gérard Genette (410) warn us that "the paratext is only an assistant, only an accessory to the text"? Therefore, such references will be made cautiously, considering the authorial epitext as yet another interpretation of a specific text that might shed some light on the author's intention on writing of a specific text, but not as a meaning necessarily created by the work itself.

\section{The portrayal of divisions}

In the three texts, the concept of division manifests itself in multiple ways. The Blind Kingdom, a political allegory, starts with an apocalyptic scene of a terrible earthquake, unbearable heat, anguish, suffering and death (10) sweeping away all former political hierarchies and injustices (11). In a political sense, the space becomes a tabula rasa, peopled with men and women who are all equal just like in the beginning of time. Subsequently this fictional world is invaded by the Blind with their invincible army, dominating the rest of the population. Blindness and Vision thus form two opposing symbolic fields underlying the unfolding of the intrigue. Blindness is associated with dictatorial oppression; the exclusion of the Other, inequality, the refusal to share power (especially with a woman) and corruption. Tadjo draws on imagery from nature to render the idea of a dictatorship that stifles the country. In "A Conversation with Janis Mayes", an interview on The Blind Kingdom, she explains that this catastrophe refers to the end of colonisation and the beginning of a new era, here depicted as the reign of the Blind. To render the oppression of this post-colonial dispensation, the author chooses the image of a bat: the palace of King Ato IV who reigns over the blind kingdom, has the form of this animal associated in the text with "the force of darkness" (Blind Kingdom 14), which extends its wings far over the city (13). ${ }^{2}$ The decorations of the royal abode are all too reminiscent of the palace of Versailles, associated with the colonisers of the Ivory Coast. Real bats also invade the kingdom soiling everything with their excrement which is hard to remove. Images of draught, pollution, heaps of refuse and stench prevail in this setting.

King Ato IV's reign divides the city into two realms: firstly, the realm of the Blind and the realm of the Others, the Sighted, who are living in misery, and secondly into the Great North where people can see, and by implication, the South, where blindness reigns. It follows logically that the characters in these texts would also belong to these opposing camps: thus the blind Akissi, the daughter of Ato IV falls in love with Karim from the North. Vision is associated with the excluded Other whose visage cannot even be seen by the Blind. Vision represents true insight, community, sharing, life, energy and change. 
In the aforementioned interview on The Blind Kingdom, Tadjo points out that she had post-independence African states in mind when creating the character of King Ato IV. She adds that, although already published in 1990, the story parallels current divisions, that is "the North/South" divide within Côte d'Ivoire caused by "the rebellion which took place in September 2002" and which "marked the beginning of a deep political and military crisis" (Conversation). From other interviews one can also gather that the author is deeply concerned about political and social conflict in Cote d'Ivoire, a problem which she grapples with in most of her works.

In Queen Pokou, the second text, the divisions are clearly political in nature and unequivocally linked to the history of Côte d'Ivoire. Right from the start, the reader is confronted with the complexities of conflict and divisions in Africa caused by a struggle for power. A war of succession within the same family-yet again a family is at the source of the conflict-forces Queen Pokou and her followers to leave the Ashanti kingdom (Ghana today), as Pokou's only male child is considered a threat to the throne. The group of refugees arrive at the Comoé River that is in flood and they cannot go any further. After consultation with the spirits of the water, it becomes clear that a human sacrifice in the form of a noble child is required to cross the water. Pokou decides to throw her only and long awaited child in the water in order to save her people, who can then cross the river and establish a new territory, the kingdom of the Baoule meaning "the child is dead".

Apart from the obvious division between Ashanti and Baoulé, and the separation necessary to found a new nation, Tadjo explains in a 2011 lecture on the political upheaval in her country yet another form of division attributed to the Pokou legend. She points out that under Félix Houphouët-Boigné the tale "became part of the collective imagination and acquired the status of a national myth that portrayed the Baoulé people as the true custodians of Ivorian identity" ("Of saviours, gods and domination"). In other words, the foundational legend became a motif to exclude non-baouléen Ivoriens from the nation, to consider them as the unwelcome Other. However, Tadjo's deconstruction of the myth about the origins of the Baoule people changes it into a polysemic metaphor of not only the hardships of African people caused by historical events which opposed them to Westerns nations, for instance the slave trade, but also of Good versus Evil as a given of human existence. As Dina Ligaga (487) so aptly observes, "Multiple narratives contest totalizing structures and offer possibilities for alternative voices, as is the project that Tadjo undertakes".

The North/South divide in Côte d'Ivoire again serves as the backdrop for Far from my father, published in 2010 before the upheavals of 2011, but this time the story is firmly anchored in reality, and situated in Abidjan after the rebellion of 2002. On top of this initial division, the separation between the Self and the Other is internalised within the protagonist's own mind. After the death of her father, Nina, born from a French mother and an Ivorian father, finds herself torn between modernity and 
tradition, between her Western and African heritages. Nina feels "far" from this father; different from her family; unwelcome in her own country. The character of Nina is placed in an in-between situation, reminiscent of Homi Bhabha's interstice (30), highlighted by the configuration of secondary characters amongst whom she evolves. It should be noted that the family, with its internal divisions and conflicts, becomes a trope for the nation in this text, and indeed in all three the texts, as in other African novels written by women (Toivanen 99-126). Frequent references to the political problems of Côte d'Ivoire broaden the scope of the intrigue to a questioning of the post-colonial Ivorian state.

\section{Ideals of healing and perspectives of hope}

Tadjo herself makes no secret of the fact that she is committed to overcome division and to open up possibilities for hope: "You look beyond destruction to let life in again," (Conversation) observes the author in the interview on The Blind Kingdom. The question arises as to how Tadjo achieves this in her texts, without resorting to what Dominick LaCapra (154) would call a redemptive narrative.

In all three texts, Tadjo presents the reader with two main sources of renewal: on the one hand the importance of rethinking traditions, and, on the other hand, drawing on cultural heritage. They are profoundly interconnected, as the following examples will show.

In The Blind Kingdom a sorcerer orders Akissi to let herself be impregnated by "a man [...] who will come to see many things at once" (note vision versus blindness) but most importantly a man who "will rethink our traditions without negating them" (94-5), like the author herself. It turns out that this man is Karim, Akissi's lover, who comes from the realm of the Sighted. Akissi falls pregnant, an image of full commitment to truth (Conversation) according to Tadjo, thus fulfilling the old sorcerer's prediction that she will become the carrier "of great hope: a new generation who will set energy free, open closed doors and create new paths" (Blind Kingdom 95). Moreover, in The Blind Kingdom the importance of cultural heritage as a source to be drawn upon becomes apparent in the role of prophets, sorcerers, chants and rites that go together with the belief in an invisible world beyond reality, characteristic of African animism. In the Great North the old man who performs rites of initiation on Akissi to cure her from her blindness, calls on "all the invisible beings living in the holy forest. He calls on the founders of the village, on the Ancestors, the guardians of secrets" (Blind Kingdom 92). Tadjo herself quotes this passage to make a plea for not merely doing away with these forms — dare I say—of indigenous knowledge because that "would erase a whole new range of possibilities" (Invisibility 3). After Akissi's initiation and her new insight into the problems of her father's reign, she returns, joins Karim and falls pregnant. Tadjo doesn't present the reader with an unequivocal victory of Vision over Blindness. In fact the text underscores the complexity of choices 
and the hardships to be endured in the process of opposing oppression. The text finally juxtaposes Karim's death-he is hanged-to the start of Akissi's contractions. The story ends with the disappearance of the bats and a potential sign of hope in the birth of twins, a boy and a girl (signaling gender equality), who embody a new generation capable of representing the vision to go beyond the original divisions.

The second example: in Queen Poko, the author's deconstruction (rethinking) of the Pokou legend brings her to propose a new ending to the tale, entitled "The time of the bird-child". Tadjo endows the deceased child with wings: he soars over a world full of tears, suffering and fear. The child returns to "combat against the evils of all times" (Queen Poko 94). This embodiment of hope and salvation comes from the African soil itself: "Man, woman, bird. I am the old man, the child of the young man. I am the young man, the son of the child. Born from the bush and the forest and the crammed town" (Queen Poko 95). Having taken on another form, the child is no longer subject to death and becomes so powerful that he is able to kill the snake that brought destruction to the world: "and the bird-child laughs, he raises his arms to the heaven. He has conquered the beast" (Queen Poko 96). Tadjo thus opens up new modes of understanding for a politically abused legend: in her narrative it becomes a myth drawn from African cultural heritage, dealing with universal problems such as mankind's propensity to exclude or to violently eliminate the Other. In her own words: "I [...] remind readers that we are all migrants" (Lecture). Tadjo transforms the tale into a depiction of the eternal battle of Good against Evil, of sacrifice in order to restore peace, not only in a specific country, but amongst mankind. The new ending suggests a vision of hope that stays within the register of the legend or the myth, genres which serve to educate the reader or listener about moral behaviour.

My third instance is the novel Far from my Father. The text is anchored in contemporary African society and also linked to the author's own life. It offers yet another perspective on how the author envisages overcoming divisions; however, in this case, in a more practical and contemporary way. Once more, Tadjo questions what has become of African traditions, in particular the custom of the prolonged funeral and the institution of polygamy. There are two dimensions at work in the narrative: firstly, the plot is based on the drawn-out process of organising Nina's father's funeral, culminating in the last chapter with the scene of the burial itself. Secondly, most of the péripties - the twists and turns of the plot-are linked to the tradition of polygamy, when Nina gradually discovers the existence of four siblings, of whom she knew nothing, born from her father's unofficial relationships. In her interviews on this book, Tadjo reveals her intention to question the current corruption and perversion of these two customs. The text stages Nina's dismay when she discovers how corrupt employees extort money and gifts from the deceased's family all through the lengthy and often delayed stages of the preparations for her father's funeral. As far as polygamy is concerned, Tadjo highlights the plight of offspring born from 
unofficial relationships. Previously, when polygamy was officially practiced, children from such marriages enjoyed social recognition and financial protection, whereas presently they are marginalised and ignored by families. Tadjo not only underscores from a modernist point of view her main character's disbelief and irritation with the many incidents of corruption surrounding her father's funeral, but also shows how Nina must decide, against her family's wishes, to take care of her siblings, thus correcting the social injustices of unofficial polygamy.

Nevertheless, other African traditions, especially art forms like the folktale, are yet again considered a rich source of wisdom holding solutions for current problems. As already indicated Far from my father does not only deal with Nina's personal challenges, but also with those of a country on the verge of civil war. When Nina's half-sister Cécile tells her the tale of two brothers who had to go through a process of conflict and rupture to eventually establish a prosperous kingdom, a tale which underscores the idea of compromise, solidarity and joint responsibility, Nina, like Karim, can see more than only what meets the eye. Finding compromises with her aunts, appreciating a sense of belonging surrounded by her new family, she finally, together with the others, finds a way forward in her new circumstances and assumes the immense responsibilities that go with it. Cécile's folktale subtly introduces a wider applicability to Nina's story and suggests that healing for the post-colonial state is possible if everybody contributes to rebuilding a nation.

In addition to the folktale as a source for renewal, other forms of art also play a positive role in these three texts: in one version of the Pokou legend, the carefully sculpted wooden statue of her child consoles Pokou and enables her to find peace after his death. The Mask in the Blind Kingdom holding the power to restore Akissi's vision, is made out of the red fabric of a beautifully woven garment. As Tadjo puts it herself: "It is important that as a people, we recognize that our cultural diversity is a source of richness" (Conversation). In all three novels and in the rest of her oeuvre, African culture, be it rites, chants, folktales or artefacts, is associated with the solutions proposed by the narratives, but in a nuanced, open-ended way.

\section{The agency of women and female characters in the process of bringing about change}

After I have dealt with Tadjo's ideals of healing and perspectives of hope, the stage is set for her views on the agency of women and female characters in the process of effecting salubrious social change. All the female protagonists in the corpus selected for this study have to go through a process of separation and initiation and two of them (Akissi and Nina) have to be reintroduced into their previous environments to be able to bring about renewal. Tadjian female characters have to make choices that can have good or bad consequences and they are never allowed to resort to an attitude of Sartre-like bad faith. The intervention of a female character is needed in order to find solutions and a way forward. 
Akissi is the only person in the reign of the Blind who cannot be controlled by her megalomaniac of a father. King Ato IV acknowledges that he is powerless against her-not being able to force her to marry someone of his choice (Blind Kingdom 15). The king regrets not having been able to father a son with whom he would have been able "to conquer the whole world" (16). The fact that the stubborn Akissi is his only heir, adds a feministic slant to Tadjo's text: Akissi becomes the first to transgress the Law of the Father, and to leave her father's kingdom for the Great North, where her mother originated from. In the realm of the Sighted she is welcomed, protected and instructed by yet another woman, namely Karim's mother. This character is reminiscent of the figure of the old woman in the African folktale, a genre that "establish[es] the tradition of women as insightful and resourceful problem solvers" (Mbelle 61). Although the traditional African folktale is misogynist (Lee 20), "a woman gains a certain amount of power when she is old" (27). Karim's mother is given a role often assigned to older women in folktales and legends, namely that of mentor and guide. Moreover, she has the "knowledge of secrets" and is able to speak "the language of the initiated" (Blind Kingdom 73). She also has the right to request the start of rituals for Akissi's initiation to true vision. She assists and guides the young woman when an old man calls on the spirit of the powerful Mask, the "source of life" (79), linked to truth and vision, to heal Akissi from her blindness. It is from her that Akissi will learn "the myths and legends of her people" (78) and how to confront the problems of her father's reign.

The figure of Queen Abraha Poko, descendant from a matrilineal dynasty, is a prime example of the complexity of female agency in Tadjo's work. The original legend, as recounted by Tadjo, depicts Pokou as being chosen by the spirits of the clan for "a great destiny" (12). The story of her life foregrounds her courage, insight and leadership qualities and her ability to save her people through personal sacrifice. Nevertheless, through Tadjo's deconstruction of the legend, the figure of Pokou loses her monolithic Amazon-like nature to be only a mother grieving about the loss of her beloved child and questioning the fact that women must always sacrifice their sons to save kingdoms (42). In this version of the legend, Pokou can only become the founder of a new nation after having received restoration for her loss in the form of the wooden statuette resembling her son. In yet another rewriting, Pokou embodies the abuse of power (female power) or becomes the epitome of the malicious, vengeful seductress.

Nina, the fictional "descendant" of both Akissi and Pokou, is not a princess but also enjoys a certain social status as the daughter of Kouadio Yao, who during his lifetime, played an important role in the Ivorian society. In spite of an epigraph to Loin de mon père (9) underscoring filiation passing from father to son, it is Nina, the second daughter, on whom the family relies to handle the problems her father left them with. After a process of re-introduction to her roots, Nina finally over- 
comes her initial reluctance and takes charge of her newly found family after her father's death.

Tadjo aligns herself with other contemporary African female authors who question traditional patriarchy and subscribe to female agency (see Toivannen 102). Odile Cazenave, a proponent of African feminism, considers Tadjo as representative of a new generation of "rebellious" female writers who "search for new alternatives to the socio-political problems of a stagnant post-colonial Africa and create feminist/ female voices contrasting sharply with canonical masculine authority" (14). Cazenave defines African feminism as follows: "Feminist Africain consciousness admits the inequalities and limitations imposed on women in pre-colonial Africa, it acknowledges its affinities with international feminism but in its objectives, envisages an African feminism" (Kingué \& Cazenave 642). The roots of Tadjo's specific form of feminism may well lie in her own cultural roots. Her father was a descendant from the Akan, a "matrilineal people" according to Tarikhu Farrar (585), who adds that "[e]very office in the Akan political hierarchy (in all its variants) has its male and female counterparts" (588) contrary to some other African peoples. Furthermore, as far as the binary male/female in Tadjo's three texts is concerned, she does not subscribe to merely privileging female over male in a simplistic fashion. The role of male characters is significant: without Karim, Akissi cannot become an agent for change. Karim becomes a sort of Christ who has to die, who is sacrificed, in order to obtain salvation. Poko's male child also has to be sacrificed and his return in the form of a bird signals hope; Nina needs her ex-boyfriend Kangha's advice and her recently found half-brother Amon's help to find solutions to all the problems she inherited after her father's death. In Tado's oeuvre female agency is inscribed in a context where the solidarity of a whole community of women and men is needed in order to achieve change.

Nevertheless, in all three of the texts , finding solutions and taking responsibility are never depicted as being uncomplicated: Tadjo's poignant depictions of Karim and Akissi's self-doubt; Nina's hesitations and initial refusal to take responsibility; the questioning of the Pokou figure's bravery, all illustrate that these women are not heroines in the traditional sense of the word. As the author very significantly observes: "There is no saviour, Ivorians are fully aware of it. If Côte d'Ivoire is going to gain lasting stability and development, it will come from the country as a whole." (Lecture)

This remark by Tadjo brings me to the values of solidarity, community and unity that are so pronounced in her oeuvre: Princess Akissi has to go out to the people of the North where she is unconditionally accepted and advised by the whole community; on her own, the grieving Pokou can't find any solace and Nina must step out of her in-between situation and has to depend on the advice and support of others to find her way. 


\section{Going beyond generic boundaries}

From a stylistic point of view it is significant that Tadjo's representation of division goes beyond generic boundaries to open up a rich variety of perspectives on the problems she deals with. In typical postmodern fashion Reine Poko. Concerto pour un sacrifice proposes alternative readings of the traditional legend in the form of four different scenarios with four different endings. Furthermore, the text is divided into three sections: the legend, the questioning of the legend and the last section entitled "The time of the bird-child", forming the coda of the concerto (see Vassilatos 141) in which Tadjo structurally overcomes division by going further than the content of the legend in order to envisage a time of hope when evil will be vanquished. The Blind Kingdom is a collection of short texts told from different points of view without any clear chronological sequences of events. Poetic passages containing prophecies or evoking rites and chants, alternate with monologues and inner dialogues in order to create a poetic modern legend or tale which allows for multiple allegorical interpretations. Far from my father defies the definition of autofiction by avoiding any onomastic identity between author, narrator and protagonist, in spite of biographical details being clearly reworked in the text. The focalisation shifts without transition from Nina to her father in order to create a better understanding of her father's actions. Information on mating habits of insects, the content of a booklet on sorcery, letters and e-mails are reproduced and presented without much accompanying commentary, so that it is up to the reader to collaborate in the construction of meaning and to link all these archives to the overarching concerns of the novel. All these literary devices give a unique stylistic quality to Tadjo's engagement with the African continent.

In conclusion it may be surmised that Tadjo's texts tackle the issues we live by: division and separation, be it the North-South divide in Côte d'Ivoire, Brexit versus the European Union, or fundamentalism (of whichever variety) versus the secular state. Véronique Tadjo consistently strives in her œuvre to counteract division and separation by promoting solidarity, compromise and caring for the Other. She makes it abundantly clear that these values are already embedded African culture, a source from which new creative modes of shaping the future of the continent can be drawn.

\section{Notes}

1. For the sake of clarity, the English titles of all the original French works written by Tadjo are used in this article. However, the dates of publication are those of the original French texts. .

2. All references to these texts refer to the original French editions. Except when otherwise indicated, all quotations from Tadjo's three texts are my own translations.

\section{Works Cited}

Bhabha, Homi K. Les lieux de la culture. Une théorie postcoloniale. Payot, 2007.

Cazenave, Odile. Femmes rebelles. Naissance d'un nouveau roman africain au féminin. Harmattan, 1996.

Farrar, Tahriku. "The Queenmother, Matriarchy and the Question of Female Political Authority in Precolonial West African Monarchy." Journal of Black Studies, vol 27, no 5, 1997, pp. 579-97. 
Genette, Gerard. Paratexts: Thresholds of Interpretation (Literature, Culture and Theory). CUP, 1997.

Kingué, Adèle \& Odille Cazenave. "Pour l'enseignement des écrivains femmes africaines dans le cours de français." The French Review, vol 70, no 5, 1997, pp. 641-57.

Lacapra, Dominick. Writing History, Writing Trauma. The John Hopkins University Press, 2001.

Ligaga, Dina. "Re-imagining and re-writing the legend of Queen Pokou." African Identities, vol 9, no 4, 2011, pp. 487-91, http://dx.doi.org/10.1080/14725843.2011.615163.

Mbelle, Joseph. "Women in the African Epic." Research in African Literatures, vol 37, no 2, 2006, pp. 61-7.

Tadjo, Véronique. "A Conversation with Janis Mayes." African Writing Online, vol 4, no. 2, Dec. 2016, http:// www.african-writing.com/four/veroniquetadjointerview.htm.

. Le Royaume aveugle. Harmattan, 1990.

. "Lifting the cloak of invisibility. A writer's perspective," Research in African Literatures, vol 44, no 2, 2013, pp. 1-7.

. Loin de mon père. Actes Sud, 2010.

. "Of saviours, gods and domination: The rise and fall of Laurent Gbagbo." James S. Coleman Memorial Lecture Series. James S. Coleman African Studies Centre UCLA. U of California. Lecture. 18 Mar 2011.

. Reine Pokou. Concerto pour un sacrifice. Edicef, 2011.

Toivanen, Anna-Leena. "Daddy's Girls?: Farther-Daughter Relations and the Failures of the Postcolonial Nation-State in Chimanda Ngozi Adichie's Purple Hibiscus and Véronique Tadjo's Loin de mon père". Ariel: A Review of International English Literature, vol 44, no 1, 2013, pp. 99-126.

Vassilatos, Alexia. "Au croisement des cultures. Reine Pokou de Véronique Tadjo au niveau des études supérieures dans le contexte sud-africain". French Studies in Southern Africa, vol 40, 2016, pp. 132-48. 